O.A. Dorozh, PhD, Assoc. Prof., V.I. Kovalchuk, PhD, Assoc. Prof., I.L. Kozlov, DSc, Prof.

Odessa National Polytechnic University, 1 Shevchenko Ave., Odesa, Ukraine, 65044

\title{
MODERN TECHNOLOGIES IN THE SYSTEM OF REGENERATION AND PURIFICATION OF BORON CONCENTRATE
}

О.А. Дорож, В.І. Ковальчук, І.Л. Козлов. Сучасні технології в системі регенерації і очищення борного концентрату. Виконано аналіз ефективності технологічного ланцюжка типової установки СВО-6. Виявлено характерні недоліки, властиві комбінованим системам «випарювання-іонообмінне фільтрування», обумовлені властивостями борної кислоти і витісненням хлоридів аміаком з швидким виснаженням аніонітних фільтрів. Показана можливість заміни існуючої схеми високотехнологічною баромембранною технологією на базі сучасних бороселективних мембран.

Ключові слова: спецводоочистки, бор, борна кислота, мембрани

O.A. Dorozh, V.I. Kovalchuk, I.L. Kozlov. Modern technologies in the system of regeneration and purification of boron concentrate. The analysis of the efficiency of the technological chain of a typical installation (device) SVO-6 is performed. Characteristic drawbacks, inherent in combined "evaporation-ion-exchange filtration" systems conditional to the properties of boric acid and the displacement of ammonia by ammonia with rapid depletion of anionite filters, are revealed. The possibility of replacing the existing scheme with high-tech baromembrane technology based on modern boroselective membranes is shown.

Keywords: special water treatment, boron, boric acid, membranes

Introduction. Among means of supporting the quality of coolants in the first circuit of a nuclear power plant is the system of regeneration of boron concentrate SVO-6 [1]. It provides purification and concentration of boron-containing water, in order to return to the cycle of boron concentrate and purified condensate.

Analysis of recent research and publications. Boron-containing waters are formed from:

- coolant, withdrawn from the first circuit in the process of water exchange/makeup;

- accumulation of the pit of the organized leaks of the first circuit;

- freshly prepared boron concentrate from agitator tanks;

- boron concentrate from boron concentrate tanks;

- purified concentrate of drainage water.

The substances contained in them are typical for the first circuit during its operation (see table), and are accumulated as a result of contact with the equipment surfaces and radiochemical reactions.

The design scheme SVO-6 is based on evaporation technology and includes: an evaporative unit, ion exchange filters for the purification of boron concentrate and distillate. The water from the tanks of the reactor department in the evaporator evaporates to a boric acid concentration of $39.5 . . .44 .5 \mathrm{~g} / \mathrm{dm}^{3}$. Secondary steam after condensation, degassing and after-cooling is subjected to purification on ionexchange filters and merges into control tanks. The boron concentrate is drained into a tank of "dirty" boron concentrate and, after after-cooling, is fed to the mechanical and ion-exchange filters for cleaning.

The present in the water ammonia easily passes into the secondary vapour and, at a high concentration, rapidly depletes the cationite filter. Due to the "breakthrough" of this ion, the filters are transferred to the regeneration mode. Purification of boron concentrate is accompanied by saturation of the cation exchanger with $\mathrm{K}^{+}, \mathrm{NH}_{4}{ }^{+}$ions and transfer of anionite to the $\mathrm{H}_{3} \mathrm{BO}_{3}$ form.

The "breakthrough" of $\mathrm{K}^{+}, \mathrm{NH}_{4}{ }^{+}$leads to an increase in $\mathrm{pH}$ after CF. Due to the fact that the anionite of the $\mathrm{H}_{3} \mathrm{BO}_{3}$-form in a neutral and alkaline medium has a very low exchange capacity for chlorides and other anions, cationite filters after the transition to the $\mathrm{K}^{+}, \mathrm{NH}_{4}{ }^{+}-$form must be regenerated. 
Quality of boron-containing waters

\begin{tabular}{c|c|c|c|c}
\hline Index & $\begin{array}{c}\text { Unit of } \\
\text { measurement }\end{array}$ & Initial & Distillate & Concentrate \\
\hline Sodium (lithium, potassium) & $\mathrm{mg} / \mathrm{dm}^{3}$ & $1,0 \ldots 10,0$ & $>1.0$ & $<1.0$ \\
\hline Chlorides & $\mathrm{mg} / \mathrm{dm}^{3}$ & 0,1 & $>0.10$ & $\leq 0.15$ \\
\hline Ammonia & $\mathrm{mg} / \mathrm{dm}^{3}$ & $\geq 5,0$ & - & - \\
\hline Boric acid & $\mathrm{g} / \mathrm{dm}^{3}$ & $0,5 \ldots 20,0$ & - & $(16 \ldots 20) /(39.5 \ldots 44.5)$ \\
\hline Corrosion Products & $\mathrm{mg} / \mathrm{dm}^{3}$ & $\leq 0,05$ & - & - \\
\hline $\mathrm{pH}$ & - & - & 6.5 & $\geq 4.2(3.8)$ \\
\hline Volume -activity on dry matter & $\mathrm{Bq} / \mathrm{m}^{3}$ & - & $7.4 \cdot 10^{3}$ & - \\
\hline
\end{tabular}

The duration of operation of the VU is limited by the condition that the control levels of aerosol emissions to the atmosphere are not exceeded.

The scheme can be represented by a structure in the form of series-parallel blocks (Fig.1).

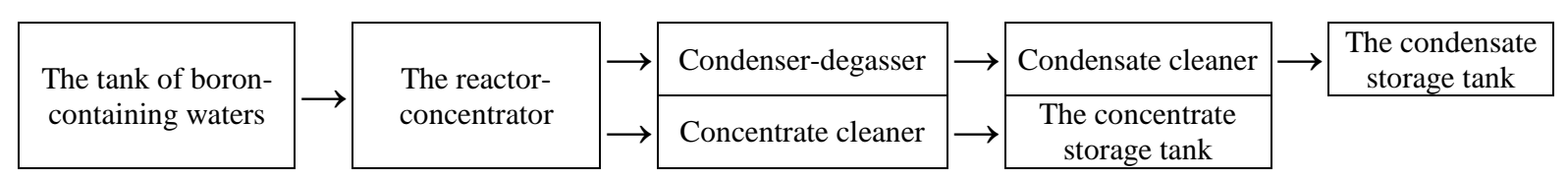

Fig. 1. Block diagram of a system for the concentration and purification of boron-containing waters

The presence of an evaporation apparatus as a concentrator is not a virtue; it requires energy resources for operation. The combination of molecular and dissociated forms of boric acid significantly reduces the efficiency of ion-exchange cleaning.

In aqueous solutions B2O3 dissolves to form boric acid. The forms of boric acid as a function of $\mathrm{pH}$ are presented in Fig. 2. In acid medium $(\mathrm{pH}<6)$ these are mainly molecular $(\mathrm{H} 3 \mathrm{BO} 3)$ and associated (H3BO3OH-) forms of orthoboric acid. In alkaline waters $(\mathrm{pH}>7)$ there are slightly dissociated forms of tetra-, penta-, hexa- and other polyboric acids of the general formula $\mathrm{nB} 2 \mathrm{O} 3 \cdot \mathrm{mH} 2 \mathrm{O}$ or $\mathrm{H} 3 \mathrm{~m}$ $2 \mathrm{nBmO3m}-\mathrm{n}$. The orthoboric form of the anion $\mathrm{H3BO} 3 \mathrm{OH}-[2]$ is predominant in the $\mathrm{pH}$ range $8 \ldots 12$.

When the reactor unit is operating at power, the $\mathrm{pH}$ values, with a boric acid concentration of up to $10.0 \mathrm{~g} / \mathrm{dm}^{3}$, are in the range $5.9 \ldots 10.3$.

During the physical start-up and before the output of power by the reactor, the $\mathrm{pH}$ value, with a boric acid concentration of less than $16.0 \mathrm{~g} / \mathrm{dm}^{3}$, is $5.7 \ldots 7.2$.

Comparison of the $\mathrm{pH}$ values of the evaporation products and the forms of the acid allows us to assume inefficient concentration of ion exchange filters in the neutral acid region due to the deficit of ionized forms.

The purpose of the study is the possibility of application of membrane technologies that can be an alternative to the design scheme.

Presentation of the main material. Reverse osmosis (RO) technologies for removal of boron from natural waters began to be applied relatively recently, which was due to the lack of borselective membranes and membrane elements based on them on the market.

The efficiency of separation of impurities by membranes is assessed by their selectivity:

$$
R=1-\frac{C_{p e r}}{C_{\text {init }}},
$$

where $c_{\text {init }}$ and $c_{\text {per }}$ - concentrations of components of the initial mixture and permeate.

The selectivity value of the reverse osmosis membrane according to borate and polyborate ions is significantly higher than for boric acid, since the dimensions of the latter are close to the dimensions of water molecules (Fig. 3).

The selectivity of most industrial low-pressure RO membranes for boron at neutral $\mathrm{pH}$ values of water does not exceed $50 . . .70 \%$, high-pressure membranes $-80 \ldots .85 \%$ [3]. 


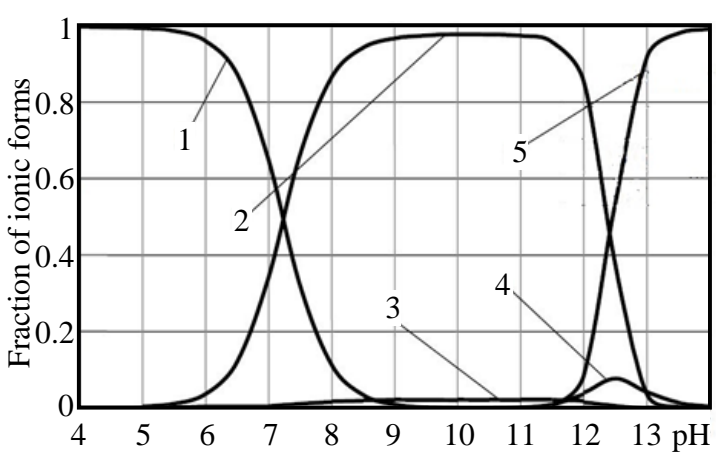

Fig. 2. Ratio of dissociated forms of orthoboric acid in the coolant: 1 - molecular form of $\mathrm{H}_{3} \mathrm{BO}_{3} ; 2$ - anion of the first degree of the association $\mathrm{H}_{3} \mathrm{BO}_{3} \mathrm{OH}^{-}$; 3 - anion of the first degree of dissociation of $\mathrm{H}_{2} \mathrm{O}_{3}{ }^{-}$; 4 - anion of the second stage of dissociation of $\mathrm{HBO}_{3}{ }^{2-}$;

5 - anion of the third degree of dissociation $\mathrm{BO}_{3}{ }^{3-}$

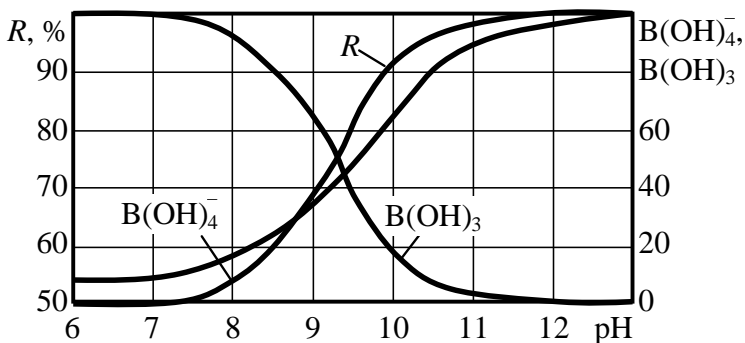

Fig. 3. Selectivity of Filmtec and Hydranautics membranes in relation to boron, depending on the $\mathrm{pH}$ of the solution

Results. Experimental studies of the dependence of the selectivity of low- (Filmtec, Hydranautics) and medium-pressure (OPMN-P, ESPA-1) membranes on $\mathrm{pH}$ are presented in Fig. 4 [4]. The selectivity of membranes with respect to boron compounds correlates well with the data in Fig. 2, the selectivity of high-pressure marine membrane elements being much higher than that of low-pressure membranes.

Effects of boron content in the initial water in the concentration range from 2.5 to $20.5 \mathrm{mg} / \mathrm{dm}^{3}$ on the selectivity of the low-pressure reverse osmosis membrane have not been observed over the entire $\mathrm{pH}$ range. As it can be seen from the graph in Fig. 5, the experimental points in the entire range of boron concentrations uniformly deviate from the approximating relationship of the form:

$$
R=0.16 \mathrm{pH}^{5}-7.984 \mathrm{pH}^{4}+155.65 \mathrm{pH}^{3}-1483 \mathrm{pH}^{2}+6918,8 \mathrm{pH}-12616 \text {. }
$$

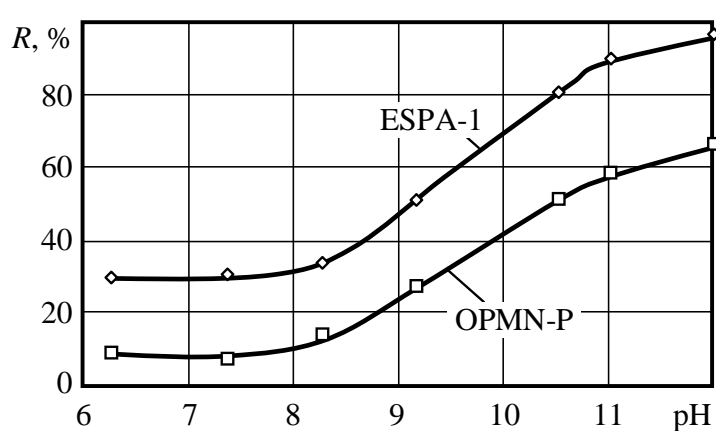

Fig. 4. Selectivity of ESPA-1 and OPMN-P membranes for boron,depending on the $\mathrm{pH}$ of the solution

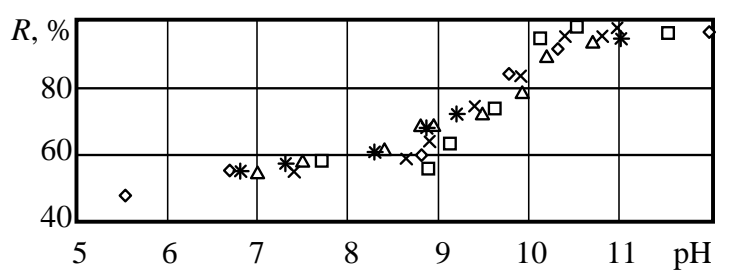

Fig. 5. Selectivity of membranes by boron, depending on the $\mathrm{pH}$ of the initial concentrations of boron compounds: $\diamond-2.5$; $\square-4.8 ; \Delta-8.7 ; x-10$; * $-20.5 \mathrm{mg} / \mathrm{dm}^{3}$

Increasing the $\mathrm{pH}$ of the treated water above 8.8 increases the selectivity from $45 \%$ to $92 . . .95 \%$ at $\mathrm{pH}>10.5$. Further increase in $\mathrm{pH}$ does not cause a noticeable effect.

The highest efficiency of membrane concentration of boric acid is observed with respect to its hydrated forms.

High-pressure Dow Chemical and Hydranautics membranes have increased selectivity to boron. In the latter, the ESPA B series, the increase in selectivity is manifested at a $\mathrm{pH}$ greater than 8.5, 
reaching $96 \%$ at $\mathrm{pH}=10$. This necessitates the alkalization of water before feeding to the borelective membranes.

Conventional membranes have boron selectivity of 90 to $92 \%$, and there are also specialized membranes that have greater selectivity to conventional membranes.

Studies of selectivity and retention of general purpose membranes TFC-3012-200, performed in the laboratory of the department of water and fuel technology, showed that the concentration factor reaches 9.6...9.7. Selectivity for boron compounds is $0.674 \ldots . .0 .741$.

The obtained results made it possible to form a scheme for the installation of SWT-6, without the use of evaporators, ion-exchange filters, trap filters and

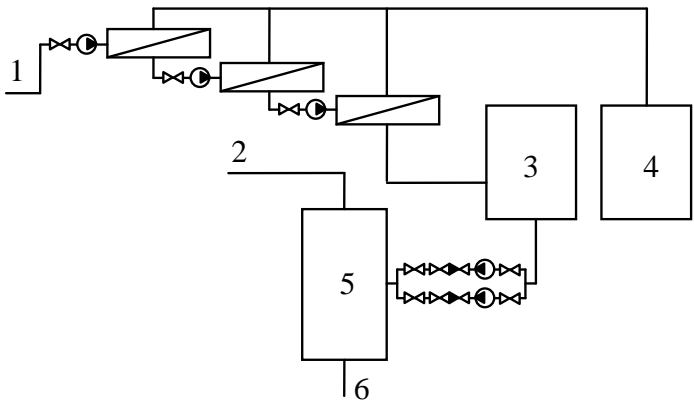

Fig. 6. Technology system chart of SWT-6 on the basis of membrane technologies: 1 - From the drain water tank; 2 - For ventilation; 3 Permeate tank; 4 - Concentrate tank5 - Jetcyclone degasser; 6 - For cleaning other elements (Fig. 6). The scheme consists of:

- membrane plants, consisting of roll membrane elements installed in a special housing;

- collection tanks for permeate and concentrate;

- jet-cyclone degasser for the removal of radioactive gases from the permeate;

- special pumps for membrane elements, pumps for transferring concentrate and permeate streams, pipelines and shut-off valves.

The projected device eliminates the drawbacks of the existing SVO-6 scheme. It allows increasing the efficiency of SVO-6, increasing the reliability of the installation, reducing the energy costs that were significant due to the operation of the evaporator, reducing material costs, reducing metal consumption and reducing the overall dimensions of the system.

\section{Conclusion.}

- the projected system for the concentration and purification of boron-containing waters is based on energy-intensive and resource-intensive technology;

- modern membrane technology is able to solve the problems of concentrating and cleaning boron-containing water with reduced energy and resource costs;

- laboratory studies confirm the possibility of using general purpose membranes in the scheme.

\section{Література}

1. Техническое описание и инструкция по эксплуатации. Система очистки борного концентрата CВО-6 (ТD), 171-6/3,4-Э-ХЦ. 2012. - Кузнецовск. РАЭС - 111 с.

2. Ковальчук, В. И. Борная кислота в теплоносителе первого контура АЭС / В. И. Ковальчук, И. Л. Козлов, И. П. Аседач // Труды Одесского политехнического университета. - 2009. - № 2. - С. 46 - 48.

3. Бабак Ю. В. Извлечение соединений бора из воды в процессе баромембранной обработки [Электронний ресурс] / Ю. В. Бабак, Л. А. Мельник, В. В. Гончарук // Промышленная екологія. - Т. 2. C. 563 - 565. - Режим доступу: http://eco.com.ua/sites/eco.com.ua/files/lib1/konf/3vze/zb_m/ t2/tom_2_s06_p_563_565.pdf

4. Прохоров И. А. Очистка воды Каспийского моря от примесей бора и промышленное получение воды питьевого качества: автореф. дис. на соискание уч. степени канд. тех. наук: спец.05.17.01 «Технология неорганических веществ» / И. А. Прохоров. - Москва, 2009. - 20 с.

\section{References}

1. Tekhnicheskoye opisaniye i instruktsiya po ekspluatatsii. Sistema ochistki bornogo kontsentrata SVO-6 (TD), 171-6/3,4-E-KHTS [Technical description and instruction manual. The system for cleaning boron concentrate SVO-6 (TD), 171-6 / 3,4-E-HC]. (2012). Kuznetsovsk: RNPP. 
2. Kovalchuk, V. I. Kozlov, I. L., \& Asedach, I. P. (2009). Bornaya kislota v teplonositele pervogo kontura AES [Boric acid in the coolant of the primary circuit of a nuclear power plant]. Trudy Odesskogo politekhnicheskogo universiteta - Odes'kyi Polytechnichnyi Universytet. Pratsi. 2, 46-48.

3. Babak, Yu. V., Melnik, L. A., \& Goncharuk, V. V. Izvlecheniye soyedineniy bora iz vody v protsesse baromembrannoy obrabotki [Extraction of boron compounds from water in the process of baromembrane processing]. Promyshlennaya yekologíya - Industrial ecology. - Vol. 2, 563-565. Retrieved from: http://eco.com.ua/sites/eco.com.ua/files/lib1/konf/3vze/zb_m/t2/tom_2_s06_p_563_565.pdf

4. Prokhorov, I. A. (2009). Ochistka vody Kaspiyskogo morya ot primesey bora i promyshlennoye polucheniye vody pit'yevogo kachestva [Purification of water from the Caspian Sea from boron impurities and industrial production of drinking water]. Extended abstract of candidate's thesis. Moscow. 